International Review of Research in Open and Distributed Learning Volume 19, Number 4

\title{
A Framework for Implementing OER-Based Lesson Design Activities for Pre-Service Teachers
}

\author{
Dongho Kim \\ University of Florida
}

\begin{abstract}
The demand for qualified teachers with sufficient pedagogical knowledge and skills is high. However, existing teacher education programs do not provide adequate experiences through which to develop preservice teachers' professional foundations. This study recognized Open Educational Resources (OER) as a means by which to address the issue of enhancing teacher education. The purpose of this study was to propose a framework to be used to integrate OER into lesson design activities for pre-service teachers. In this study, a focused literature review investigated the frameworks of distributed cognition and examplebased learning. This review process resulted in a unified framework that provides a description of how preservice teachers learn with OER at both the individual and cognitive system levels. Four principles and 10 guidelines are provided to guide the implementation of OER-based lesson design activities in real settings. The new framework has the potential to enhance pre-service teachers' Web resource-based professional development.
\end{abstract}

Keywords: open educational resources, lesson design, pre-service teacher education, example-based learning, distributed cognition 


\section{Introduction}

A training period is critical for pre-service teachers because it is in that time that the largest influence occurs on their pedagogical knowledge and skills (Milner, 2010). Pre-service teachers acquire pedagogical knowledge and the related necessary skills to teach during a practicum or similar opportunity, such as a field observation (Liu, 2012). However, pre-service teachers assigned to schools for their training are exposed to limited practice while observing a few mentor teachers. As such, many beginning teachers often struggle to teach in real-life teaching situations (Blomberg, Stürmer, \& Seidel, 2011).

One solution to the limitations of conventional pre-service teacher training is Web resource-based professional development. The forms of Web resource-based professional development range from formal online curricula offered by educational institutions to informal online learning, such as using online resources or participating in online teacher communities (Chen, Chen, \& Tsai, 2009). Web resource-based training may also help pre-service teachers learn to receive just-in-time assistance and acquire situationspecific knowledge (Dede, Jass Ketelhut, Whitehouse, Breit, \& McCloskey, 2008).

Open educational resources (OER), which are released under an open license that permits their free use or repurposing (Atkins, Brown, \& Hammond, 2007), have the potential to support pre-service teachers' Web resource-based professional development. Permissions called 4Rs (i.e., Reuse, Revise, Remix, and Redistribute) differentiate OER from other types of resources and support the extensive use of OER (Wiley, Bliss, \& McEwen, 2014). OER can serve as both learning and teaching resources because of their capacity to be freely adapted to new contexts under open licenses (Hassler, Hennessy, Knight, \& Connolly, 2014). As pre-service teachers experience meaningful learning while discovering some form of intellectual property represented in OER, they can imagine how they might also adapt existing resources for their future students.

As the OER movement rapidly grows, more repositories dedicated to teachers (e.g., OER commons) are increasingly available. The dedicated repositories offer high quality materials for various purposes and serve as a community of educators. While structured OER (e.g., textbooks, complete courses) are often used "as-is" with little modification, unstructured OER (e.g., video clips, pictures) offer great flexibility for adaptive use.

This study noted the potential of OER for pre-service teachers' lesson design activity. The ability of OER to be adapted fits the nature of lesson design activities that involve creative processes, such as planning lessons and creating digital teaching materials. However, little research provides practical guidelines for integrating Web resources into lesson design activities.

The purpose of this study was to propose a framework by which to implement an OER-based lesson design activity that was based on two theories: The theory of distributed cognition and example-based learning. Both theories are concerned with the roles of external representations in enhancing cognitive processes of learners from different angles (Dyer et al., 2015; Zhang, 1997). This study recognized OER as external resources that represent existing teaching practices and noted the potential synergy of two distinct frameworks for providing an explanation as to how OER can support pre-service teachers' lesson design activities at both individual and cognitive system levels. The theory of distributed cognition serves as a lens 
through which to view OER as cognitive resources. The framework provides an insight into interactions between individuals (i.e., pre-service teachers) and cognitive resources (i.e., Web resources). Although the theory of distributed cognition is a useful framework through which to understand how cognitive resources amplify individual cognition at a cognitive system level, it falls short of explaining the internal learning mechanism. The example-based learning framework was thus employed to describe pre-service teachers' internal learning processes when learning from Web resources.

\section{Method}

\section{Focused Literature Review}

For this study, a focused literature review was conducted to find, analyze, and synthesize studies that addressed the frameworks of distributed cognition and example-based learning. Specifically, the following steps were taken. First, the theoretical frameworks of distributed cognition and example-based learning were investigated. Second, commonalities between these two theoretical frameworks were identified. Then, these commonalities were used as crucial connecting points for the construction of a novel unified framework. Following the construction of this new framework, principles and guidelines by which to implement this framework in practice were formed.

Initially, the sole author of this study undertook a search of 12 databases including ERIC, PsycINFO, and SocINDEX with Full Text using EBSCOHOST. An extensive search was used because the two theoretical frameworks had been addressed in multiple disciplines, such as education, sociology, anthropology, and informatics. The keywords searched were "example-based learning" and "distributed cognition(s)". To identify relevant studies on distributed cognition, either "technology" or "resource" were used as additional search terms. The search was limited to academic articles and books published between 1996 and 2016. The initial search resulted in 656 studies.

\section{Criteria-Based Selection}

In order to include only relevant studies, this study used some selection criteria. The author carefully examined the keywords, titles, and abstracts of the studies. The identified studies were finally included if they addressed the following topics within the two theoretical frameworks: learning with external resources or technology, knowledge acquisition, and/or knowledge transfer. The author excluded studies that did not address learning processes with resources or technology such as interface design research or usability test reports. As a result, 28 studies were identified to be relevant and used to examine the two theoretical frameworks. 
Kim

\section{Literature Review}

\section{Theory of Distributed Cognition}

The theory of distributed cognition provides a framework through which to explain how thinking and learning take place in a cognitive system consisting of individuals and artifacts that have cognitive properties (Perkins, 1997). This concept assumes that learners' cognitions are distributed across human minds, artifacts, and groups of people as part of a larger cognitive system (Zhang \& Patel, 2006). Cognitive processes are observed both inside and outside of human minds (Davies \& Michaelian, 2016). Cognitive processing takes place when humans collectively use the distributed cognition that resides in external cognitive resources, such as other humans, symbolic media, the environment, and artifacts (Perkins, 1997). Individuals, with assistance of external resources can complete a cognitive task beyond their cognitive ability (Xu \& Clarke, 2012; see Figure 1).

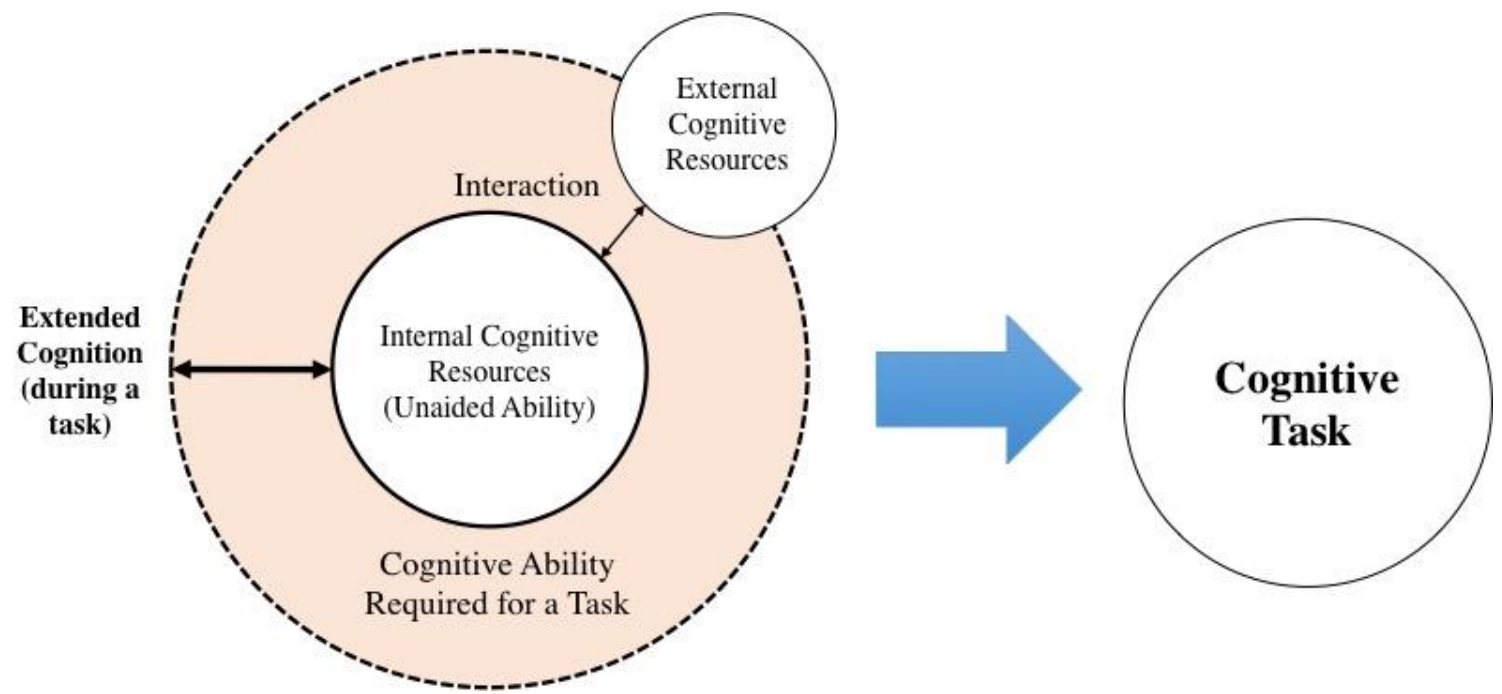

Figure 1. Theory of distributed cognition.

Distributed cognition researchers study a social system, while the traditional cognition researchers focus on individual cognitive processes (Morgan, Brickell, \& Harper, 2008). As such, they pay attention to a collection of individuals, artifacts, and their interactions based on a comprehensive view that encompasses several research lines, such as sociology and cognitive science (Blandford \& Furniss, 2006). According to distributed cognition theorists, the cognitive properties of a system cannot be fully understood from the cognitive properties of the individual components (Zhang \& Patel, 2006). The distributed cognition approach is mainly concerned with the function of the cognitive system and seeks to understand how learners configure the environment to achieve a goal in the system (Xu \& Clarke, 2012).

The theory of distributed cognition sheds light on individuals' extensions of cognition, which result from functional relationships among elements, including various forms of representations and physical tools, in a cognitive system (Xu \& Clarke, 2012). The operations of cognitive systems can be described based on two main representational states: internal and external (Toon, 2014). Internal representations are the cognitive resources (i.e., knowledge and structure) in individuals' minds, while external representations are the 
cognitive resources outside of the individuals (Morgan et al., 2008; Zhang \& Norman, 1994). Cognition is viewed as the interaction between the individual and the surrounding representations involved in a cognitive activity (Morgan et al., 2008). Learners configure an environment in which they can use various types of external resources to accomplish a cognitive task (Xu \& Clarke, 2012).

The notion of distributed cognition is distinctively characterized by its unique view of cognition as an information flow. Cognition flows across a variety of representations and individuals use cognitive properties as vehicles of thought to complete cognitive tasks (Perkins, 1997). The use of various types of external representations (e.g., diagrams, graphs) enhances access to essential knowledge as well as aids in information processing (Zhang, 1997). The completion of cognitive tasks is the result of "the interwoven processing of internal and external information that generates much of a person's intelligent behavior" (Zhang \& Patel, 2006, p. 334). One individual, therefore, does not necessarily need to take on the entire extent of the cognitive task (Belland, 2011). Individuals, instead, engage in the coordination of distributed cognition to accomplish a cognitive task.

However, the extension of cognition does not necessarily imply a perpetual state of individual cognition (Perkins, 1997). Rather, the theory of distributed cognition poses that cognition is amplified during the use of a technology in a particular cognitive task (Davies \& Michaelian, 2016). Meaningful learning requires learners to plan and organize behaviors to accomplish a cognitive task, and this process is referred to as executive functioning (Landry, Smith, \& Swank, 2009). In the process, learners assume executive control that "supervises the selection, initiation, execution, and termination of each task" (Rubinstein, Meyer, \& Evans, 2001, p. 763). In technology-supported learning environments, learners cede part of their executive function to external cognitive properties to overcome the lack of internal cognitive resources (Belland, 2011). Meaningful learning for transferable knowledge gain happens when learners gradually gain back their executive function as they gain mastery of a given task (Perkins, 1997).

The concept of transfer of executive function assumes that effective learning takes place when learners maintain their executive control "throughout the executive function of the system" (Belland, 2011, p. 584). Learners should, thus, be encouraged to independently select a path of action, explore accessible representations, and construct knowledge (Perkins, 1997). When accomplishing a given cognitive task, learners should actively engage in cognitive processing to situate relevant resources (Morgan et al., 2008). In computer-supported learning environments, independent problem solving is possible when learners are allowed to "make choices, explore consequences of options, and otherwise make decisions regarding strategies" (Belland, 2011, p. 584). In essence, during the different phases of learning, learners should remain as a cognitive agent (Landry et al., 2009).

\section{Theory of Example-Based Learning}

Example-based learning is an effective approach when students possess insufficient prior knowledge of a particular task (Atkinson, Derry, Renkl, \& Wortham, 2000). For novice students, engaging in problemsolving without exposure to model examples is not an effective method (Van Gog \& Rummel, 2010). The example-based learning framework encompasses three lines of research that focus on different types of examples: worked examples, modeling examples, and analogies. This study addressed worked examples 
and modeling examples because the analogical reasoning approach is largely dependent on whether an appropriate analogy is available (Holyoak, 2012).

According to Renkl (2014), despite varying applications of example-based learning that depend on example types or contexts, a consistent theme exists regarding phases of knowledge acquisition (see Figure 2). Firstly, in the observation and rule identification phases, learners observe relevant information from examples in order to identify abstract rules or principles (Renkl, 2014). They then engage in cognitive processing in order to coordinate the external information in accordance with the information retrieved from their schema, a step which involves high-level information processing such as reasoning or inference (Renkl, 2014). Finally, learners construct their schema by incorporating the new information (internalization), which is followed by the elaboration of the schema for later occasions (elaboration) (Renkl, 2014).

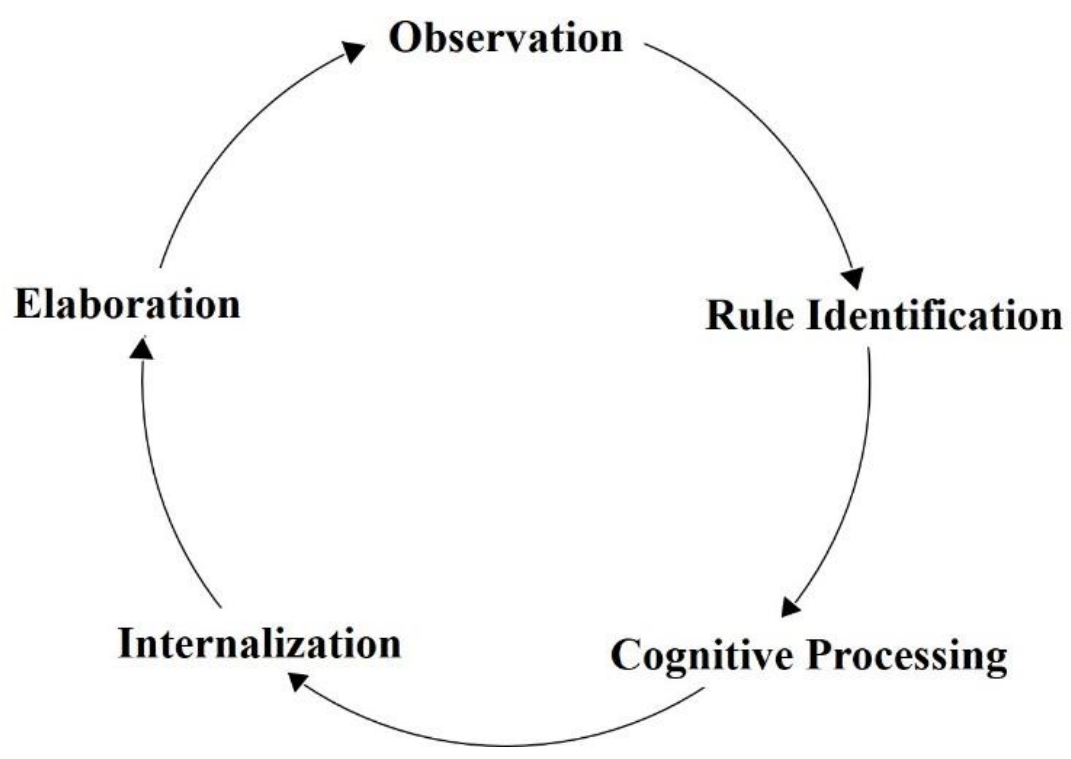

Figure 2. Learning process with examples.

\section{Worked examples.}

Worked examples allow learners to learn from a problem for which the solution is described (Crippen \& Earl, 2007). Learners are, for example, presented key principles and steps that lead to a final solution in mathematics (Hilbert, Renkl, Schworm, Kessler, \& Reiss, 2008). Worked examples are usually written accounts that show ideal or didactical procedures (Van Gog \& Rummel, 2010).

Cognitive load theory provides an important theoretical foundation for the use of worked examples. Cognitive load is defined as "the load that performing a particular task imposes on the cognitive system" (Paas, Tuovinen, Tabbers, \& Van Gerven, 2003, p.64). Novice learners often become overburdened when having to perform complex cognitive tasks without the initial understanding of the key principles (Sern, Salleh, Lisa Sulaiman, Mohamad, \& Yunos, 2015). The lack of initial understanding may be problematic because novice learners' learning remain superficial due to limited working memory that otherwise could 
be dedicated to in-depth information processing (Van Gog \& Rummel, 2010). Worked examples help learners focus on the important aspects of problems in order to avoid making mistakes or inefficiently studying to reach the intended solution (Dyer et al., 2015). The effects of worked examples are not limited to well-defined problems from particular domain subjects but also can be expanded to ill-defined problems in which learners are required to engage in critical decision-making or reasoning processes (Atkinson et al., 2000; Crippen \& Earl, 2007; Dyer et al., 2015).

\section{Modeling examples.}

Modeling examples are generated using social models that perform particular tasks. A social model can use a real person, humanoid agent, or symbolic model. Modeling examples show various approaches by which to solve problems as opposed to worked examples that mostly show ideal procedures and solutions (Hoogerheide, Loyens, \& van Gog, 2014). Coping models, for example, display erroneous performances and how to overcome them (Kitsantas, Zimmerman, \& Cleary, 2000). Modeling examples entail the presence of social models and salient contextual information, such as social models' appearances or voices (Van Gog \& Rummel, 2010). Models display cognitive patterns that learners need to perform and the demonstration encapsulates abstract representations of extensive domain knowledge and advanced skills (Angeli, 2005).

Observational learning with modeling examples relies on social sources in the beginning, while the shift to a self-learning phase occurs later in this process (Van Gog \& Rummel, 2010). Schunk and Zimmerman (2007) highlighted the transitional process of observational learning from its social phases to its selfcontrolled phases. The shift to the self-controlled phase should happen as learners gradually internalize skills or strategies exhibited by social models (Bandura, 2001).

Using modeling examples contributes to the development of complex cognitive skills. Learners can acquire cognitive representations through observations in the form of schema (Morgan et al., 2008). Modeling examples help build cognitive schemas, which enable learners to use learned behaviors on later occasions (Van Gog \& Rummel, 2010).

Modeling examples have been used in teacher education as a means to teach complex teaching skills (Ertmer, 2003). Pre-service teachers who studied expert modeling examples exhibited a more effective use of technologies in their lessons than did those pre-service teachers who created lessons without modeling examples (Angeli, 2005). Similarly, mentor teachers demonstrating technology integration in a science lesson led to pre-service teachers' integration of content knowledge into their lesson designs (Jang \& Chen, 2010).

\section{Consistent Themes in Distributed Cognition and Example-Based Learning Frameworks}

While the distributed cognition perspective seeks to understand cognitive processes at a system level, example-based learning is concerned with learning processes at the individual level (see Table 1). It is logical that distributed cognition would be used to understand the interactions between an individual learner and 
Web resources. On the other hand, the example-based learning framework explains the internal learning processes of the learner. Despite the different emphases used to explain cognitive processes, consistent themes underlie both theories that enables their integration into a unified framework.

First, the role of external representations is emphasized in regard to evoking cognitive processing. From the distributed cognition perspective, humans amplify their cognition by coordinating representational states using representational resources, such as media, device, and technologies (Belland, 2011). The example-based learning theory also focuses on how to incorporate relevant representations in examples to facilitate learners' cognitive processes. (Renkl, 2014; Van Gog \& Rummel, 2010).

Second, both theories focus on increasing novice learners' cognitive capacities. The distributed cognition framework supports the notion that an individual learner, with the assistance of cognitive resources, is capable of solving complex problems that are beyond their abilities (Belland, 2011). The example-based learning framework describes two types of examples that contribute to reducing learners' unnecessary cognitive burdens. Worked examples are used to reduce learners' cognitive loads by directing their attention to the important aspects of a problem (Wittwer \& Renkl, 2010). The modeling example also highlights the gradual internalization of the information exhibited by the social models.

Third, in-depth cognitive processing appears to be essential to constructing internal representations and transferring knowledge. From the distributed cognition perspective, cognitive processing plays a crucial role in helping learners coordinate cognition across internal minds and external representations (Zhang \& Patel, 2006; Morgan et al., 2008). The example-based learning theory also supports the need for cognitive processing for transferable knowledge acquisition. For learning with worked or modeling examples to be transferred to solve other novel problems, information processing opportunities, in addition to a given example, should be provided (Van Gog \& Rummel, 2010; Renkl, 2014).

Finally, both theories highlight the importance of the transition from reliance on external representations to self-control phases. The distributed cognition framework indicates that meaningful learning (i.e., the internalization of external resources) is observed when learners play a central role in the cognitive system (Perkins, 1997). Although learners rely on surrounds in early phases of a cognitive task to overcome their limited cognitive capacity, they gradually gain back their autonomy as they progress (Belland, 2011). Example-based learning research has also illustrated the transitional process of observational learning from social to self-regulated phases (Schunk \& Zimmerman, 2007). After observing and emulating models' behaviors, a shift to the 'self-controlled phase' should happen, in which the learner incorporates the observed representations into their schema (Bandura, 2001). 
Table 1

Consistent Themes in Distributed Cognition and Example-Based Learning Regarding Cognitive Processes

\begin{tabular}{|c|c|c|}
\hline \multicolumn{2}{|c|}{ Cognitive processes } & \multirow{2}{*}{ Consistent theme } \\
\hline Distributed cognition & Example-based learning & \\
\hline $\begin{array}{l}\text { Cognition is amplified through } \\
\text { coordinating representational states } \\
\text { of external tools }\end{array}$ & $\begin{array}{l}\text { Examples facilitate learners' } \\
\text { internal resources to facilitate } \\
\text { cognitive processes }\end{array}$ & $\begin{array}{l}\text { The importance of } \\
\text { external representations } \\
\text { for evoking cognitive } \\
\text { processing }\end{array}$ \\
\hline $\begin{array}{l}\text { Novice learners, with the assistance } \\
\text { of external cognitive resources, can } \\
\text { solve problems beyond their ability }\end{array}$ & $\begin{array}{l}\text { Examples help novice learners } \\
\text { reduce unnecessary cognitive } \\
\text { burdens }\end{array}$ & $\begin{array}{l}\text { The importance of } \\
\text { external representations } \\
\text { for increasing cognitive } \\
\text { capacity }\end{array}$ \\
\hline $\begin{array}{l}\text { In-depth cognitive processing helps } \\
\text { learners coordinate internal and } \\
\text { external resources }\end{array}$ & $\begin{array}{l}\text { In-depth cognitive processing helps } \\
\text { learners acquire transferable } \\
\text { knowledge }\end{array}$ & $\begin{array}{l}\text { The importance of in- } \\
\text { depth cognitive } \\
\text { processing }\end{array}$ \\
\hline $\begin{array}{l}\text { Meaningful learning takes place } \\
\text { when learners gain back their } \\
\text { autonomy }\end{array}$ & $\begin{array}{l}\text { Meaningful learning takes place } \\
\text { when learners successfully } \\
\text { transition from the observation } \\
\text { phase to the self-control phase }\end{array}$ & $\begin{array}{l}\text { The importance of the } \\
\text { transition from reliance } \\
\text { on external } \\
\text { representations to self- } \\
\text { control phases }\end{array}$ \\
\hline
\end{tabular}

\section{New Framework for OER-Based Lesson Design Activity}

A number of OER repositories exist that offer high quality OER created by experienced teachers or experts (for more details, see Clements \& Pawlowski, 2012). A majority of the licenses assigned to OER, unless otherwise prohibited (e.g., No Derivative Works), permit unlimited modification and adaption. A lesson design activity involving the manipulation of cognitive resources is expected to lead to the construction of the enhanced internal representations of pre-service teachers who initially have insufficient internal resources.

Figure 3 shows the new framework that integrates the distributed cognition and example-based frameworks. Pre-service teachers interact with external cognitive resources (OER) in order to accomplish design tasks. OER serve as both examples and design materials. The learning process reflects the same mechanism as in example-based learning. Pre-service teachers, in the early phases, observe examples by which to identify abstract rules of representation. They, then, increasingly internalize the representations 
through the adaptation of OER. Once the internalization process is completed in pre-service teachers' schema, their extended cognition outlasts the design task. Subsequent reflection and revision help them to refine their designs as well as elaborate their schema. As the lesson design process progresses, pre-service teachers gradually have executive control over their lesson designs. Pre-service teachers become independent of the inherent design or context of the original resources and focus on their own teaching contexts.

In summary, the lesson design activity with OER focuses on supporting pre-service teachers' transitions from observation to internalization. Pre-service teachers have the opportunity to integrate OER into their existing schema, while engaging with the design of a lesson.

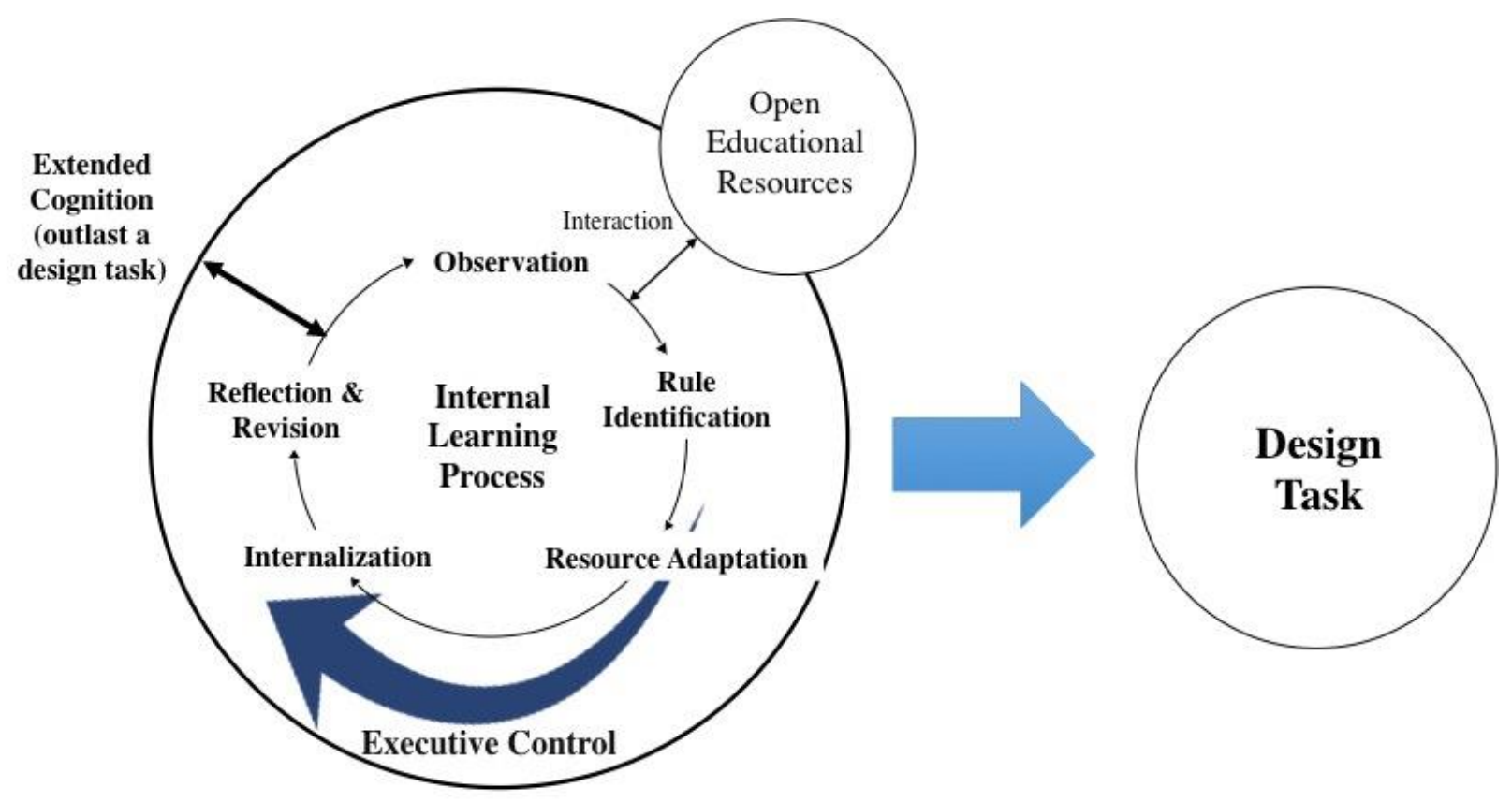

Figure 3. New framework for integrating OER into lesson design.

\section{Principles and Guidelines for Implementation}

Based on the proposed unified framework, four principles and guidelines for the implementation of an OER-based design activity are suggested (see Table 2). Corresponding lesson design phases were adapted from Angeli's (2005) model. This nine-phase model was chosen because it is specifically situated in teacher education contexts, and intended to guide pre-service teachers in designing a lesson using pedagogically appropriate technology. This study tailored the model to an OER-based lesson design activity and the following six steps are suggested: choosing a topic, observing teaching strategies, planning class activities, developing materials, evaluation, and revision. 
Table 2

Principles and Guidelines for Implementation of OER-based Lesson Design Activity

\begin{tabular}{lll}
\hline Step & Lesson design phase & Principle \& Guideline \\
\hline & & $\begin{array}{l}\text { Have pre-service teachers explorer oer that } \\
\text { take different approaches to the same topics }\end{array}$ \\
\cline { 2 - 4 } $\begin{array}{l}\text { Observation / } \\
\text { Rule } \\
\text { Identification }\end{array}$ & $\begin{array}{l}\text { Choosing a topic } \\
\text { Observing teaching } \\
\text { strategies }\end{array}$ & $\begin{array}{l}\text { Encourage pre-service teachers to find OER } \\
\text { that represent both worked (e.g., lesson } \\
\text { plans) and modeling examples (e.g., } \\
\text { classroom practice videos). }\end{array}$ \\
& $\begin{array}{l}\text { Encourage pre-service teachers to explorer } \\
\text { OER that show a variety of pedagogical } \\
\text { methods (e.g., collaborative learning, } \\
\text { project-based learning). }\end{array}$ \\
& $\begin{array}{l}\text { Engage pre-service teachers in comparing } \\
\text { identified OER in order to identify the } \\
\text { critical features. }\end{array}$ \\
\hline
\end{tabular}

\section{Facilitate in-depth cognitive processing}

- Have pre-service teachers come up with ideas to improve identified OER.

- Have pre-service teachers revise and remix OER to their own lesson design contexts.

$\begin{array}{lll}\text { Resource } & \circ & \begin{array}{l}\text { Planning class } \\ \text { activities }\end{array} \\ \text { Adaptation / } & & \begin{array}{l}\text { Developing materials } \\ \text { / Executive }\end{array} \\ \text { Control / } & & \end{array}$

- Encourage pre-service teachers not to replicate inherent designs of original resources for their lesson design.

Control /

Internalization

Allow pre-service teachers to have increasing autonomy over their lesson designs

- Help pre-service teachers shift from observing structured OER (e.g., complete textbooks) to manipulating unstructured OER (e.g., micro content, learning objects).

- Gradually remove guidance for OER use and lesson design.

$\begin{array}{lll}\text { Reflection / } & \circ & \text { Evaluation } \\ \text { Revision } & \circ & \text { Revision }\end{array}$

Encourage peer interactions in order to improve lesson design outcomes

- Have pre-service teachers review and comment on their peers' design outcomes. 
- Have pre-service teachers reflect on and revise their lesson designs based on feedback from their peers.

\section{Principle 1: Have Pre-Service Teachers Explorer OER That Take Different Approaches to the Same Topic}

At the choosing a topic phase, pre-service teachers can benefit from exploring available materials as they learn from what topic other teachers chose and how the topic is taught in class. Observing teaching strategies used by other teachers help pre-service teachers discover important rules and principles for teaching. Being exposed to different pedagogical approaches also allows them to observe the consequences of implementing the approaches in classrooms, which is considered a form of observational learning. The exploratory observation would contribute to identifying what class activities pre-service teachers want to implement to teach the chosen topic effectively.

In Example-based learning, a first-schema abstraction does not necessarily transfer to other problem contexts (Renkl, 2014). The opportunity to compare multiple examples helps learners discover the critical aspects of a problem as well as gain deep insights into the content (Große \& Renkl, 2006). Therefore, learners need to be exposed to different examples in order to understand the structural features of problems as well as avoid getting stuck on examples' surface features (Gerjets, Scheiter, \& Schuh, 2008).

Using contrasting examples has received attention as a way by which to help novice learners "develop more differentiated knowledge structures" (Hilbert et al., 2008, p. 319). Learners tend to better concentrate on important underlying principles when they compare and contrast examples (Renkl, 2014). The mechanism is that learners become more capable of applying knowledge to widely different problems once they learn from many possible alternative solutions (Rittle-Johnson \& Star, 2007).

It is also important to use a variety of examples for the acquisition of different skills (Renkl, 2014). Generally, worked examples are more suitable to teaching highly structured skills, such as calculation, because they present ideal solution procedures (Van Gog \& Rummel, 2010). On the other hand, modeling examples often include irrelevant details or distracting information in order to represent realistic settings (Renkl, 2014). Therefore, modeling examples are suitable for directing learners' attention to complex situations.

\section{Principle 2: Facilitate In-Depth Cognitive Processing}

The main purpose of a lesson design activity is to prepare pre-service teachers for real-world teaching. A lesson design activity should, thus, support pre-service teachers' cognitive processes for knowledge construction (Doppelt \& Schunn, 2008). Deep inquiry and reflection are required in order to enable preservice teachers to construct transferable knowledge from design-based learning (Kolodner et al., 2003). Fortus, Dershimer, Krajcik, Marx, and Mamlok-Naaman (2004) identified the manipulation of information as a crucial design process that leads to knowledge construction in science. 
At the planning class activities phase, pre-service teachers come up with ideas regarding how to transform representations they observed from OER into concrete activities that can be implemented in their classroom. OER are created in the local context of use, therefore they cannot be "simply transposed to a new setting" (Ponti, 2014, p. 155). There should be a process by which pre-service teachers internalize content. The developing materials phase is for pre-service teachers to deconstruct and recontextualize content represented in the OER (Littlejohn \& Hood, 2017).

As previously described, the distributed cognition perspective stresses learners' engagement with cognitive processing as a method that leads to the construction of internal representations. It is important that the distributed cognition framework describes internal cognitive processing as being tightly coupled with the processing of external representations (Liu, Nersessian, \& Stasko, 2008). To perform cognitive tasks, learners first need to process both the information provided by the external representations and the information retrieved from their internal representations (Zhang \& Patel, 2006).

Previous research has provided theoretical and empirical evidence that cognitive processing contributes to knowledge construction. For example, Morgan et al. 2008 suggest that High-level processing of content should be undertaken in order to enable learners to gain an enhanced understanding of knowledge as well as produce more structured learning outcomes. Zhang and Patel (2006) recognized information processing as an essential activity by which to construct knowledge. Individuals can only generate intellectual outcomes through activities that help integrate perceived external representations and retrieve internal representations (Zhang \& Patel, 2006). OER have inherent designs (Conole, McAndrew, \& Dimitriadis, 2010; Ponti, 2014), and users are required to deconstruct and adapt the resources to their pedagogical patterns. Design activities involving the adaptive use of resources lead to an in-depth understanding of the content to be taught (Conole et al., 2010).

\section{Principle 3: Allow Pre-Service Teachers to Have Increasing Autonomy Over Their Lesson Designs}

Koehler and Mishra (2005) emphasized that participants of design activities should be the creators of knowledge rather than the consumers of it. Design involves learners' critical decisions in the process of creation as they undertake several iterative processes (e.g., exploring resources, revising solutions, reflecting on outcomes) to obtain satisfactory design outcomes (Doppelt \& Schunn, 2008). A lesson design activity, in this regard, should give pre-service teachers autonomy over their design products.

The distributed cognition framework highlights the importance of a gradual increase in learner autonomy (Belland, 2011). Learners' autonomies in the distributed cognition framework imply that learners choose courses of actions and make autonomous decisions in order to define problems and devise solutions. Perkins (1997) argued that when learners rely on instructional guidance and tools, they do not get back their autonomy in the later phase of learning. The absence of transition to independent control over external resources engenders shallow learning if learners leave their executive control to external resources despite the completion of a target task. A transfer of responsibility can be achieved when learners maintain the executive control of given tasks (Belland, 2011). Allowing gradual increases in learner autonomy helps learners prepared for the transfer of learning. 
The example-based learning approach also stresses the gradual shift to the self-regulated phase of learning. Learners rely on provided examples at the beginning of their learning, but increasingly internalize relevant principles and become ready to reproduce them in varying contexts (Schunk \& Zimmerman, 2007). Example-based learning can, thus, be considered a form of scaffolding (Dyer et al., 2015). As outlined by Dyer et al., 2015, examples provide initial assistance in regard to understanding desirable solution steps. However, once the learners discover the important key principles from the examples, they can achieve "goals that would have been beyond their abilities without guidance" (Dyer et al., 2015, p. 2). The initial guidance should, thus, be gradually faded as learners progress toward the completion of their tasks.

\section{Principle 4: Encourage Peer Interactions in Order to Improve Lesson Design Outcomes}

In designing a lesson plan, the reflection phase is necessary to allow pre-service teachers develop a pedagogical rationale (Angeli, 2005). The revision phase that subsequently takes place leads to the refinement of lesson design as well as facilitates the design-based process (Angeli, 2005). Empirical evidence exists that shows that the mix of erroneous and correct models can be beneficial for learners when acquiring far transfer knowledge (Van Gog \& Rummel, 2010). Peer models that pose familiar challenges to pre-service teachers can, thus, be good examples (Ryalls, Gul, \& Ryalls, 2000). Peer models that correspond to the learners' levels of knowledge, in contrast, lead learners to "closer attention and deeper processing" (Renkl, 2014, p. 17).

The use of peer models has also been studied in the discipline of teacher education. Peer coaching, as a typical form of peer model-based learning, has been widely acknowledged as a method used to support teacher professional development (Ovens, 2004). Although not explicitly mentioned as example-based learning, peer coaching includes essential components of example-based learning, such as observations and the internalization of examples (Zhang, Liu, \& Wang, 2016). Ovens (2004), for example, reported that peer coaching developed pre-service teachers' teaching techniques and promoted reflection on various instructional strategies. Peer coaching was revealed to provide a supportive context within which the preservice teachers felt more accountable and committed (Ovens, 2004).

Peer coaching is more effective when learners engage in reflection and revision to improve their designs (Jenkins, Garn, \& Jenkins, 2005). Design is not a linear process completed after producing one single design artifact (Hong \& Choi, 2011). It is, rather, iterative processes that involve a series of activities in a cyclic manner (Hong \& Choi, 2011). Teacher training is not an exception. Pre-service teachers can benefit from revising their designs based on reflection which occurs in the context of peer coaching. Jang and Chen (2010), for example, implemented peer coaching for the purpose of improving pre-service teachers' TPACK. The participants shared videotapes of their teaching and coached one another to learn how to integrate a new teaching method: an activity which prompted the pre-service teachers to reflect on how to revise their lessons (Jang \& Chen, 2010). Similarly, Lee and Kim (2014) proposed an instructional design model that illustrates an iterative lesson design activity where pre-service teachers were required to review group members' video-recorded teaching videos and exchange ideas to improve their lessons. The lesson design activity involving peer coaching and subsequent revision improved their TPACK and lesson designs (Lee \& Kim, 2014). 


\section{Conclusion}

Given the potential advantages of Web resources for teacher professional development, teacher education institutes are urged to turn their attention to integrating OER into their curriculum (Cannell, Macintyre, \& Hewitt, 2015; Sapire \& Reed, 2011). Despite the growing recognition of potential advantages of OER, however, little is known about how to integrate OER into pre-service teacher training. Only few studies noted the potential of OER as a primary source for training pre-service teachers (Thakrar, Zinn, \& Wolfenden, 2009). As indicated by Hassler et al. (2014), a majority of past research has not focused on teaching and learning mechanisms that need to be carefully examined in order to enact OER in practice. As a result, discrepancies exist between a growing interest in OER as a rising phenomenon and their applications in teacher education settings (Brent, Gibbs, \& Gruszczynska, 2012). The significance of the proposed framework can be summarized as follows.

First, the unified framework overcomes what each of the two theoretical frameworks lacks in order to explain the students' learning with OER. The new framework provides a comprehensive description of how the students should interact with OER and what type of learning takes place. As discussed earlier, the theory of distributed cognition only provides a partial description of the students' internal learning processes. On the other hand, the theory of example-based learning lacks ideas on the entire cognitive system in resourceenriched learning contexts. The new framework provides insights into how lesson design activities with OER can lead pre-service teachers to interact with distributed knowledge as well as engage in sustainable professional development.

Second, practitioners would benefit from the flexibility of the proposed framework and guidelines. Preservice teachers with different interests and levels of knowledge sit in the same classroom. OER-based training would allow pre-service teachers to design their lessons at their own paces. Therefore, teacher educators can provide individualized support in response to the pre-service teachers' personal needs and challenges. Teacher education programs are often required to offer classes on interdisciplinary topics (e.g., Lee \& Kim, 2014). The use of OER has the potential to satisfy the various needs of pre-service teachers from diverse disciplines.

Furthermore, the possibility exists that the proposed framework and guidelines could be used for various groups, such as beginning teachers. Beginning teachers are known to feel the need for professional development as they are not often fully prepared for uncertain situations in practice (Avalos, 2011; Ulvik, Smith, \& Helleve, 2009). Using OER for their own purposes would help them acquire new skills as well as refine the knowledge that they acquired during their studies. 


\section{References}

Angeli, C. (2005). Transforming a teacher education method course through technology: Effects on preservice teachers' technology competency. Computers \& Education, 45(4), 383-398.

Atkinson, R. K., Derry, S. J., Renkl, A., \& Wortham, D. (2000). Learning from examples: Instructional principles from the worked examples research. Review of Educational Research, 70(2), 181-214.

Avalos, B. (2011). Teacher professional development in teaching and teacher education over ten years. Teaching and Teacher Education, 27(1), 10-20.

Bandura, A. (1986). Social foundations of thought and action: A social cognitive theory. Englewood Cliffs, NJ: Prentice Hall.

Bandura, A. (2001). Social cognitive theory of mass communication. Media Psychology, 3(3), 265-299.

Belland, B. R. (2011). Distributed cognition as a lens to understand the effects of scaffolds: The role of transfer of responsibility. Educational Psychology Review, 23(4), 577-600.

Blandford, A., \& Furniss, D. (2006). DiCoT: A methodology for applying distributed cognition to the design of teamworking systems. In S. W. Gilroy \& M. D. Harrison (Eds.), Interactive systems. Design, specification, and verification (pp. 26-38). Berlin Heidelberg: Springer-Verlag.

Blomberg, G., Stürmer, K., \& Seidel, T. (2011). How pre-service teachers observe teaching on video: Effects of viewers' teaching subjects and the subject of the video. Teaching and Teacher Education, 27(7), 1131-1140.

Brent, I., Gibbs, G., \& Gruszczynska, A. (2012). Obstacles to creating and finding open educational resources: The case of research methods in the social sciences. Journal of Interactive Media in Education, 2012(1). Retrieved from http://jime.ubiquitypress.com/articles/10.5334/2012-05/

Cannell, P., Macintyre, R., \& Hewitt, L. (2015). Widening access and OER: Developing new practice. Widening Participation and Lifelong Learning, 17(1), 64-72.

Chen, Y., Chen, N.-S., \& Tsai, C.-C. (2009). The use of online synchronous discussion for -based professional development for teachers. Computers \& Education, 53(4), 1155-1166.

Clements, K. I., \& Pawlowski, J. M. (2012). User-oriented quality for OER: Understanding teachers' views on re-use, quality, and trust. Journal of Computer Assisted Learning, 28(1), 4-14. 
Conole, G., McAndrew, P., \& Dimitriadis, Y. (2010). The role of CSCL pedagogical patterns as mediating artefacts for repurposing open educational resources. In P. Pozzi \& D. Persico, Techniques for fostering collaboration in online learning communities: Theoretical and practical perspectives (pp. 206-223). Hershey, PA: IGI Global.

Crippen, K. J., \& Earl, B. L. (2007). The impact of Web-based worked examples and self-explanation on performance, problem solving, and self-efficacy. Computers \& Education, 49(3), 809-821.

Davies, J., \& Michaelian, K. (2016). Identifying and individuating cognitive systems: A task-based distributed cognition alternative to agent-based extended cognition. Cognitive Processing, 17(3), 307-319. https://doi.org/10.1007/s10339-016-0759-4

Dede, C., Jass Ketelhut, D., Whitehouse, P., Breit, L., \& McCloskey, E. M. (2008). A research agenda for online teacher professional development. Journal of Teacher Education, 6o(1), 8-19. https://doi.org/10.1177/0022487108327554

Doppelt, Y., \& Schunn, C. D. (2008). Identifying students' perceptions of the important classroom features affecting learning aspects of a design-based learning environment. Learning Environments Research, 11(3), 195-209.

Dyer, J.-O., Hudon, A., Montpetit-Tourangeau, K., Charlin, B., Mamede, S., \& van Gog, T. (2015). Example-based learning: comparing the effects of additionally providing three different integrative learning activities on physiotherapy intervention knowledge. BMC Medical Education, 15(1). Retrieved from https://bmcmededuc.biomedcentral.com/articles/10.1186/s12909-0150308-3

Ertmer, P. (2003). Transforming teacher education: Visions and strategies. Educational Technology Research and Development, 51(1), 124-128.

Fortus, D., Dershimer, R. C., Krajcik, J., Marx, R. W., \& Mamlok-Naaman, R. (2004). Design-based science and student learning. Journal of Research in Science Teaching, 41(10), 1081-1110.

Gerjets, P., Scheiter, K., \& Schuh, J. (2008). Information comparisons in example-based hypermedia environments: Supporting learners with processing prompts and an interactive comparison tool. Educational Technology Research and Development, 56(1), 73-92.

Große, C. S., \& Renkl, A. (2006). Effects of multiple solution methods in mathematics learning. Learning and Instruction, 16(2), 122-138.

Hassler, B., Hennessy, S., Knight, S., \& Connolly, T. (2014). Developing an open resource bank for interactive teaching of STEM: Perspectives of school teachers and teacher educators. Journal of Interactive Media in Education, 2014(1). https://doi.org/http://doi.org/10.5334/2014-09 
Hilbert, T. S., Renkl, A., Schworm, S., Kessler, S., \& Reiss, K. (2008). Learning to teach with worked-out examples: a computer-based learning environment for teachers. Journal of Computer Assisted Learning, 24(4), 316-332. https://doi.org/10.1111/j.1365-2729.2007.00266.x

Holyoak, K. J. (2012). Analogy and relational reasoning. The Oxford Handbook of Thinking and Reasoning, 234-259.

Hong, Y.-C., \& Choi, I. (2011). Three dimensions of reflective thinking in solving design problems: a conceptual model. Educational Technology Research and Development, 59(5), 687-710.

Hoogerheide, V., Loyens, S. M., \& van Gog, T. (2014). Effects of creating video-based modeling examples on learning and transfer. Learning and Instruction, 33, 108-119.

Jang, S.-J., \& Chen, K.-C. (2010). From PCK to TPACK: Developing a transformative model for preservice science teachers. Journal of Science Education and Technology, 19(6), 553-564.

Jenkins, J. M., Garn, A., \& Jenkins, P. (2005). Preservice teacher observations in peer coaching. Journal of Teaching in Physical Education, 24(1), 2-23.

Kitsantas, A., Zimmerman, B. J., \& Cleary, T. (2000). The role of observation and emulation in the development of athletic self-regulation. Journal of Educational Psychology, 92(4), 811-817.

Koehler, M. J., \& Mishra, P. (2005). Teachers learning technology by design. Journal of Computing in Teacher Education, 21(3), 94-102.

Kolodner, J. L., Camp, P. J., Crismond, D., Fasse, B., Gray, J., Holbrook, J. ... Ryan, M. (2003). Problembased learning meets case-based reasoning in the middle-school science classroom: Putting Learning by Design(tm) into practice. Journal of the Learning Sciences, 12(4), 495-547.

Landry, S. H., Smith, K. E., \& Swank, P. R. (2009). New directions in evaluating social problem solving in childhood: Early precursors and links to adolescent social competence. New Directions for Child and Adolescent Development, 123, 51-68.

Lee, C.-J., \& Kim, C. (2014). An implementation study of a TPACK-based instructional design model in a technology integration course. Educational Technology Research and Development, 62(4), 437460. https://doi.org/10.1007/s11423-014-9335-8

Littlejohn, A., \& Hood, N. (2017). How educators build knowledge and expand their practice: The case of open education resources. British Journal of Educational Technology, 48(2), 499-510. https://doi.org/10.1111/bjet.12438

Liu, S.-H. (2012). A multivariate model of factors influencing technology use by preservice teachers during practice teaching. Journal of Educational Technology \& Society, 15(4), 137-149. 
Liu, Z., Nersessian, N. J., \& Stasko, J. T. (2008). Distributed cognition as a theoretical framework for information visualization. Visualization and Computer Graphics, 14(6), 1173-1180.

Milner, H. R. (2010). What does teacher education have to do with teaching? Implications for diversity studies. Journal of Teacher Education, 61(1-2), 118-131.

Morgan, M., Brickell, G., \& Harper, B. (2008). Applying distributed cognition theory to the redesign of the "Copy and Paste" function in order to promote appropriate learning outcomes. Computers \& Education, 5O(1), 125-147.

Ovens, A. (2004). Using peer coaching and action research to structure the practicum: An analysis of student teacher perceptions. New Zealand Physical Educator, 37(1), 45-60.

Paas, F., Tuovinen, J. E., Tabbers, H., \& Van Gerven, P. W. (2003). Cognitive load measurement as a means to advance cognitive load theory. Educational Psychologist, 38(1), 63-71.

Perkins, D. N. (1997). Person-plus: A distributed view of thinking and learning. In G. Salomon (Ed.), Distributed cognitions: Psychological and educational considerations. Cambridge University Press.

Ponti, M. (2014). Self-directed learning and guidance in non-formal open courses. Learning, Media and Technology, 39(2), 154-168.

Renkl, A. (2014). Toward an instructionally oriented theory of example-based learning. Cognitive Science, 38(1), 1-37. https://doi.org/10.1111/cogs.12086

Rittle-Johnson, B., \& Star, J. R. (2007). Does comparing solution methods facilitate conceptual and procedural knowledge? An experimental study on learning to solve equations. Journal of Educational Psychology, 99(3), 561-574.

Rubinstein, J. S., Meyer, D. E., \& Evans, J. E. (2001). Executive control of cognitive processes in task switching. Journal of Experimental Psychology: Human Perception and Performance, 27(4), $763-797$.

Ryalls, B. O., Gul, R. E., \& Ryalls, K. R. (2000). Infant imitation of peer and adult models: Evidence for a peer model advantage. Merrill-Palmer Quarterly, 46(1), 188-202.

Sapire, I., \& Reed, Y. (2011). Collaborative design and use of open educational resources: A case study of a mathematics teacher education project in South Africa. Distance Education, 32(2), 195-211.

Schunk, D. H., \& Zimmerman, B. J. (2007). Influencing children's self-efficacy and self-regulation of reading and writing through modeling. Reading \& Writing Quarterly, 23(1), 7-25. 
Sern, L. C., Salleh, K. M., Lisa Sulaiman, N., Mohamad, M. M., \& Yunos, J. M. (2015). Comparison of example-based learning and problem-based learning in engineering domain. Universal Journal of Educational Research, 3(1), 39-45.

Thakrar, J., Wolfenden, F., \& Zinn, D. (2009). Harnessing open educational resources to the challenges of teacher education in Sub-Saharan Africa. The International Review of Research in Open and Distributed Learning, 1O(4). Retrieved from http://www.irrodl.org/index.php/irrodl/article/viewArticle/705/1319

Toon, A. (2014). Friends at last? Distributed cognition and the cognitive/social divide. Philosophical Psychology, 27(1), 112-125.

Ulvik, M., Smith, K., \& Helleve, I. (2009). Novice in secondary school - the coin has two sides. Teaching and Teacher Education, 25(6), 835-842. https://doi.org/10.1016/j.tate.2009.01.003

Van Gog, T., \& Rummel, N. (2010). Example-based learning: Integrating cognitive and social-cognitive research perspectives. Educational Psychology Review, 22(2), 155-174. https://doi.org/10.1007/s10648-010-9134-7

Wiley, D., Bliss, T. J., \& McEwen, M. (2014). Open Educational Resources: a review of the literature. In J. M. Spector, M. D. Merrill, J. Elen, \& M. J. Bishop (Eds.), Handbook of research on educational communications and technology (pp. 781-789). Springer.

Wittwer, J., \& Renkl, A. (2010). How effective are instructional explanations in example-based learning? A meta-analytic review. Educational Psychology Review, 22(4), 393-409.

$\mathrm{Xu}, \mathrm{L} .$, \& Clarke, D. (2012). What does distributed cognition tell us about student learning of science? Research in Science Education, 42(3), 491-510.

Zhang, J. (1997). The nature of external representations in problem solving. Cognitive Science, 21(2), 179-217.

Zhang, J., \& Norman, D. A. (1994). Representations in distributed cognitive tasks. Cognitive Science, 18(1), 87-122.

Zhang, J., \& Patel, V. L. (2006). Distributed cognition, representation, and affordance. Pragmatics \& Cognition, 14(2), 333-341.

Zhang, S., Liu, Q., \& Wang, Q. (2016). A study of peer coaching in teachers' online professional learning communities. Universal Access in the Information Society, 15(58), 1-11. https://doi.org/10.1007/s10209-016-0461-4 


\section{Appendix A}

\section{Descriptions of Literature Reviewed in This Study}

\begin{tabular}{|c|c|c|c|}
\hline $\begin{array}{l}\text { Author } \\
\text { (Alphabetical } \\
\text { order) }\end{array}$ & Topic & Country & Research type \\
\hline $\begin{array}{l}\text { Atkinson et al. } \\
\text { (2000) }\end{array}$ & $\begin{array}{l}\text { A framework for designing effective instruction } \\
\text { with worked examples }\end{array}$ & $\begin{array}{l}\text { United } \\
\text { States }\end{array}$ & Conceptual \\
\hline $\begin{array}{l}\text { Bandura } \\
(2001)\end{array}$ & $\begin{array}{l}\text { Social cognitive theory and symbolic } \\
\text { communications between human and media }\end{array}$ & $\begin{array}{l}\text { United } \\
\text { States }\end{array}$ & Conceptual \\
\hline Belland (2011) & $\begin{array}{l}\text { Distributed cognition as a lens to understand the } \\
\text { effects of scaffolds }\end{array}$ & $\begin{array}{l}\text { United } \\
\text { States }\end{array}$ & Conceptual \\
\hline $\begin{array}{l}\text { Conole et al. } \\
(2010)\end{array}$ & $\begin{array}{l}\text { Cultural historical activity theory and computer- } \\
\text { supported collaborative learning enhanced by } \\
\text { existing good practices }\end{array}$ & $\begin{array}{l}\text { United } \\
\text { Kingdom }\end{array}$ & Empirical \\
\hline $\begin{array}{l}\text { Crippen and } \\
\text { Earl (2007) }\end{array}$ & $\begin{array}{l}\text { The Impact of Web-based worked examples and } \\
\text { self-explanation on students' performance, } \\
\text { problem solving, and self-efficacy }\end{array}$ & $\begin{array}{l}\text { United } \\
\text { States }\end{array}$ & Empirical \\
\hline $\begin{array}{l}\text { Davies and } \\
\text { Michaelian } \\
\text { (2016) }\end{array}$ & $\begin{array}{l}\text { Agent-based extended cognition to individuate } \\
\text { cognitive systems in performing cognitive tasks }\end{array}$ & Canada & Conceptual \\
\hline $\begin{array}{l}\text { Dyer et al., } \\
2015\end{array}$ & $\begin{array}{l}\text { Enhancing the effects of worked examples by } \\
\text { using completion examples, self-explanation, and } \\
\text { concept mapping }\end{array}$ & Canada & Empirical \\
\hline $\begin{array}{l}\text { Große and } \\
\text { Renkl (2006) }\end{array}$ & $\begin{array}{l}\text { Effects of presenting multiple worked-out } \\
\text { examples on mathematics learning }\end{array}$ & Germany & Empirical \\
\hline $\begin{array}{l}\text { Hilbert et al. } \\
\text { (2008) }\end{array}$ & $\begin{array}{l}\text { Preparing mathematics and science teachers for } \\
\text { teaching with worked-out examples }\end{array}$ & Germany & Empirical \\
\hline Holyoak (2012) & $\begin{array}{l}\text { Role of analogy as a key example of relational } \\
\text { reasoning }\end{array}$ & $\begin{array}{l}\text { United } \\
\text { Kingdom }\end{array}$ & Conceptual \\
\hline $\begin{array}{l}\text { Kitsantas et al. } \\
\text { (2000) }\end{array}$ & $\begin{array}{l}\text { Effects of modeling and social feedback on the } \\
\text { development of athletic self-regulatory processes }\end{array}$ & $\begin{array}{l}\text { United } \\
\text { States }\end{array}$ & Empirical \\
\hline $\begin{array}{l}\text { Landry et al. } \\
\text { (2009) }\end{array}$ & $\begin{array}{l}\text { Social problem solving to help school-age } \\
\text { children develop executive functioning and social } \\
\text { skills }\end{array}$ & $\begin{array}{l}\text { United } \\
\text { States }\end{array}$ & Empirical \\
\hline $\begin{array}{l}\text { Liu et al. } \\
\text { (2008) }\end{array}$ & $\begin{array}{l}\text { Use of visual representations as a means of } \\
\text { amplifying cognition }\end{array}$ & $\begin{array}{l}\text { United } \\
\text { States }\end{array}$ & Conceptual \\
\hline
\end{tabular}


Use of 'Copy and Paste' function to enhance

Morgan et al. learners' cognitive functioning and its impact on (2008) learner-computer interaction in a computer-

Australia Empirical supported writing context

\begin{tabular}{|c|c|c|c|}
\hline Ovens (2004) & $\begin{array}{l}\text { Effects of peer coaching and action research on } \\
\text { pre-service teachers' teaching skills }\end{array}$ & $\begin{array}{l}\text { New } \\
\text { Zealand }\end{array}$ & Empirical \\
\hline $\begin{array}{l}\text { Paas et al. } \\
(2003)\end{array}$ & $\begin{array}{l}\text { The combination of performance and cognitive } \\
\text { load measures for reliable estimate of the mental } \\
\text { efficiency }\end{array}$ & Netherlands & Conceptual \\
\hline Perkins (1997) & $\begin{array}{l}\text { The distribution of thinking and learning through } \\
\text { the use of tools }\end{array}$ & Israel & Conceptual \\
\hline Renkl (2014) & $\begin{array}{l}\text { Individual differences in learning from worked- } \\
\text { out examples }\end{array}$ & Germany & Empirical \\
\hline $\begin{array}{l}\text { Rittle-Johnson } \\
\text { and Star, 2007) }\end{array}$ & $\begin{array}{l}\text { Effects of comparing solution methods to } \\
\text { facilitate conceptual and procedural knowledge }\end{array}$ & $\begin{array}{l}\text { United } \\
\text { States }\end{array}$ & Empirical \\
\hline $\begin{array}{l}\text { Rubinstein et } \\
\text { al. (2001) }\end{array}$ & $\begin{array}{l}\text { The role of executive control in performing } \\
\text { multiple tasks }\end{array}$ & $\begin{array}{l}\text { United } \\
\text { States }\end{array}$ & Empirical \\
\hline $\begin{array}{l}\text { Schunk and } \\
\text { Zimmerman } \\
\text { (2007) }\end{array}$ & $\begin{array}{l}\text { The impact of modeling on children's self- } \\
\text { efficacy and self-regulated of reading and writing }\end{array}$ & $\begin{array}{l}\text { United } \\
\text { States }\end{array}$ & Empirical \\
\hline $\begin{array}{l}\text { Sern et al. } \\
(2015)\end{array}$ & $\begin{array}{l}\text { Effects of example-based learning on student } \\
\text { learning in comparison of problem-based } \\
\text { learning in an engineering class }\end{array}$ & Malaysia & Empirical \\
\hline $\begin{array}{l}\text { Van Gog and } \\
\text { Rummel } \\
\text { (2010) }\end{array}$ & $\begin{array}{l}\text { Worked examples and modeling as types of } \\
\text { example-based learning }\end{array}$ & Netherlands & Conceptual \\
\hline $\begin{array}{l}\text { Xu and Clarke } \\
\text { (2012) }\end{array}$ & $\begin{array}{l}\text { Investigating students' interaction and } \\
\text { achievement through the lens of distributed } \\
\text { cognition in a science classroom }\end{array}$ & Australia & Empirical \\
\hline $\begin{array}{l}\text { Wittwer and } \\
\text { Renkl (2010) }\end{array}$ & $\begin{array}{l}\text { Instructional explanations to support example- } \\
\text { based learning }\end{array}$ & Germany & Conceptual \\
\hline
\end{tabular}




\begin{tabular}{llll}
\hline Zhang (1997) & $\begin{array}{l}\text { The role of external representations in problem } \\
\text { solving }\end{array}$ & $\begin{array}{l}\text { United } \\
\text { States }\end{array}$ & Empirical \\
\hline $\begin{array}{l}\text { Zhang et al. } \\
\text { (2016) }\end{array}$ & $\begin{array}{l}\text { Effects of peer coaching on teacher professional } \\
\text { development }\end{array}$ & China & Empirical \\
\hline Zhang and & Affordances as distributed representations in a & $\begin{array}{l}\text { United } \\
\text { Patel (2006) }\end{array}$ & \multirow{2}{*}{ Conceptual } \\
\hline
\end{tabular}

Athabasca

University

(c) (†) 